Ankara Üniversitesi

SBF Dergisi,

Araştırma Makalesi

Cilt 74, No. 4, 2019, s. 1353 - 1375

DOI: 10.33630/ausbf.643920

\title{
DEFINITION OF TURKEY'S NATIONAL INTERESTS IN THE EARLY COLD WAR ERA: DIVERGENCE AND GONVERGENGE BETWEEN DP AND RPP IN THE 1950S
}

\author{
Dr. Öğr. Üyesi Murat Kasapsaraçoğlu \\ Antalya Bilim Üniversitesi \\ İktisadi, İdari ve Sosyal Bilimler Fakültesi \\ ORCID: 0000-0003-4786-6592
}

\begin{abstract}
National interest is a widely debated concept in the IR literature while analyzing foreign policies of states. This paper analyzes Turkey's national interests in the 1950s and argues that they were hard to define commonly for all and there were convergence as well as divergence between the government and the opposition in the definition of national interests. As a result, despite the continuity, specifically, in the development of Turkish-American relations and the Middle East policy in the first half of the decade, Middle East and Cyprus policies in the second half caused split between two sides. Such an argument can be regarded as a contribution to the third way in the literature mainly divided by the "continuity vs rupture" debate in Turkish foreign policy and definition of national interests between Democrat Party (DP) and Republican People's Party (RPP).
\end{abstract}

Keywords: National interest, Turkey, Cold war, Democrat Party, Republican People's Party

Soğuk Savaş’ın İlk Yillarında Türkiye'nin Ulusal Çıkarlarının Tanımlanmast: 1950'li Yıllarda DP ve CHP Arasindaki Benzerlikler ve Farkllliklar

\section{Öz}

Ulusal çıkar kavramı devletlerin dıs politikalarının analizinde uluslararası ilişkiler disiplini tarafından en çok tartışılan kavramlardan biridir. Bu makalenin amacı Türkiye'de 1950'li yıllarda ulusal çıkar kavramının tanımlanış şeklini analiz etmektir. Çalışmanın temel argümanı bu yıllarda Türkiye'nin ulusal çıkarlarının herkes için ortak bir tanımı olmadığının yanı sıra iktidar ile muhalefet arasında farklılıklar olduğu kadar benzerlikler de bulunduğudur. Sonuç olarak, muhalefet Türk-Amerikan İlişkileri ve Türkiye'nin 1950’li yılların ilk yarısındaki Ortadoğu siyaseti ile ilgili konularda iktidara destek verirken; bu on yılın ikinci yarısında Ortadoğu'da ve Kıbrıs'ta yaşanan krizlerle ilgili sert eleştiriler yöneltmiştir. Bu tarz bir sonuç; Cumhuriyet Halk Partisi (CHP) ve Demokrat Parti (DP) arasında dış politika alanında "devamlılık vs kopuş" tartışması etrafında bölünmüş olan literatürde; bu iki görüş arasında ortaya çıkabilecek üçüncü bir görüşe katkı sunmayı hedeflemektedir.

Anahtar Sözcükler: Ulusal çıar, Türkiye, Soğuk savaş, Demokrat Parti, Cumhuriyet Halk Partisi

* Makale geliş tarihi: 11.12 .2018

Makale kabul tarihi: 23.01.2019

Erken görünüm tarihi: 07.11.2019 


\section{Definition of Turkey's National Interests in the Early Cold War Era: Divergence and Convergence between DP and RPP in the 1950s}

\section{Introduction}

National interest is a widely debated concept in the IR literature while analyzing foreign policies of states. Theoretically, there is a debate especially between realists and consctructivists in terms of the "content" and "definition" of national interests. Since early realist thinkers like Machiavelli and Hobbes, national interests stands for "seeking the survival of a state in an anarchic world order." "Power" and "survival" are the main motives of states and rulers try to maximize these national interests. Therefore, the process of definition for national interests is regarded as "static" and national interests are considered constant for all states. Accordingly, Morgenthau argues that rulers of individual states make decisions and implement policies on behalf of their nation such as acting on the international arena, negotiating and making treaties, putting or choosing rules of foreign policy practices and more importantly maximizing their nation's interests. (Morgenthau, 1948: 73-74)

On the contrary, for constructivists, definition of national interests is a dynamic process changing with the conjuncture. In the 1990s, three forms of constructivism came to the fore: "systemic, unit-level and holistic". Systemic constructivism focuses only on the international arena and particularly interactions between states, whereas domestic politics are not taken into consideration. Alexander Wendt is regarded as the most influential figure of systemic constructivism and argues that the "identity" of the state shapes its interests and actions. There is a distinction between the "social" and "corporate" identities of the state: the social identity is the "status, role or personality that international society ascribes to a state"; the "corporate" identity is the "internal human, material, ideological, or cultural factors that make a state what it is". Reus-Smit argues that "though theoretically elegant, this form of constructivism suffers from one major deficiency: it confines the processes that shape international societies within an unnecessarily and unproductively narrow realm." (Burchill, 2005: 199) Unit-level constructivism of Katzenstein, however, fills this gap by "drawing attention to the internal, domestic determinants of 
national policies and enabling the explanation of variations of identity, interest and action across states, something that systemic constructivism obscures." (Burchill, 2005: 200) Similarly, Jutta Weldes argues that:

\begin{abstract}
"National interest is best understood as a social construction. Before state officials can act for the state, they engage in a process of interpretation in order to understand both what situation the state faces and how they should respond to it. This process of interpretation presupposes a language shared, at least by state officials involved in determining state action and by the audience for whom state action must be legitimate. This shared language is that of the national interest. The content of the national interest is produced in or emerges out of a process of representation through which state officials make sense of both their domestic and international contexts." (Weldes, 1999: 4)
\end{abstract}

All-in-all, politicians tend to define national interests to legitimize their actions in foreign policy and consolidate their support to continue their political activities. Regardless of the usage of the term, it is generally used to describe "what is best for a nation", so interests defined by rulers are regarded as interests of a nation. (Rosenau, 2006: 246-247; Furniss and Synder, 1955: 249) As a result, national interests are shaped by rulers' worldview, values, character, objectives and so on. (Rosenau, 2006: 249) However, as constructivists argue, the definition of national interests cannot be limited to a single dimension because of its multiple components such as politics, economy, military and even technology.

In the light of the debate between realists and constructivists on national interests, this paper argues that definition of Turkey's national interests was not a static process as considered in the 1950s, but it was closely tied with the international and domestic conjuncture, so there were some convergence as well as divergence between the government, Democrat Party (DP) and the opposition, mainly the former ruling party, Republican People's Party (RPP), in this process. For example, despite the consensus in the development of Turkish-American relations and the Middle East policy in the first half of the decade, Middle East and Cyprus policies in the second half caused split between two sides. More clearly, the government conducted Turkish foreign policy within the context of its own definition of national interests while the opposition approached and evaluated government's policies from its own perspective. However, these perceptions were not monolithic and constant, so they had some similarities as well as differences changing with the conjuncture. Such an argument can be regarded as a contribution to the construction of a third way in the literature 
mainly divided by the continuity vs rupture debate in Turkish foreign policy and definition of national interests between DP (1950-1960) and RPP (1923-1950). ${ }^{1}$

\section{Definition of "National Interests" and Turkish Foreign Policy (1923-1950)}

After Lausanne Treaty ${ }^{2}$ had been signed and the republic had been established in 1923, establishment of relations with Western powers and protection of status quo were regarded as Turkey's national interests. (Oran, 2006: 251-257) In this vein, Turkey began to develop its relations with the United Kingdom (UK) and France and solve its problems with Greece after the establishment of the republic. The initial problem that decision makers of republican Turkey, mainly president Mustafa Kemal (Atatürk) and prime minister İsmet (İnönü) had to face was the Mosul Question. With the failure of negotiations, in Lausanne Treaty it was stated that Turkey and the UK would solve this problem through negotiations. However, with the eruption of Sheikh Said rebellion in 1925, Turkey lost the upper hand and with the decision of League of Nations (LoN), Mosul was left to the jurisdiction of Iraq under the

1 DP period and its foreign policy have become two controversial issues in Turkish politics and political history literature since the 1960s. Politically, supporters of DP have praised its policies including foreign policy whereas its opponents have criticized the DP period and regard it as the beginning of Turkey's deviation from Kemalist principles and independent foreign policy. In the literature, there is a similar division between scholars who regard DP's foreign policy as a continuation of the RPP, especially after the second half of the 1940s, and the ones who regard it as a rupture from the RPP. For example, Oral Sander's Türk-Amerikan Illişkileri 19471964 (Ankara: İmge Kitabevi, 2016) and Erol Mütercimler and Mim Kemal Öke's Düşler ve Entrikalar: Demokrat Parti Dönemi Türk Dış Politikası (İstanbul: Alfa Yayınlar1, 2004) point out that definition of national interests in the DP period was similar to RPP especially after WWII. On the contrary, opponents of DP period heavily criticize DP's US centric foreign policy and Middle East policy as deviation from RPP's policies and these criticisms can be seen in Cem Eroğul's Demokrat Parti: Tarihi ve İdeolojisi (Ankara: İmge Kitabevi, 2003); Şevket Süreyya Aydemir's Ikinci Adam (İstanbul: Remzi Kitabevi, 2010); Metin Toker's Demokrasimizin İsmet Paşa'lı Yılları 1944-1973 (Ankara: Bilgi Yayınevi, 1991); Mehmet Gönlübol et al.'s Olaylarla Türk Dış Politikası (Ankara: Siyasal Kitabevi, 1996); Hüner Tuncer's Menderes'in Dış Politikası: Batı'nın Güdümündeki Türkiye (İstanbul: Kaynak Yayınevi, 2013) and, to some extent, Baskın Oran (ed.)'s Türk Dış Politikası (İstanbul: İletişim Yayınları, 2006).

2 For details of Lausanne negotiations and treaty see Demirci, Belgelerle Lozan: TaktikStratejik-Diplomatik Mücadele 1922-1923. 
mandate of the UK. Due to fear of fighting directly against the UK and lack of necessary military infrastructure to carry out such an operation, Turkish decision makers did not push hard for it. Solution of the Mosul problem shows that national interests, i.e. development of relations with the West and protection of sovereignty and independence, and realistic approach of decision makers dominated the agenda and Turkey gave up its claims in Mosul. In the same period, Turkey agreed with Greece on the exchange of minorities in both countries and kept pace for the development of relations. The 1920s can be regarded as the reconstruction period of Turkish foreign policy.

In the 1930s, however, Turkey tried to consolidate its power and establish close relations with its neighbors. Relations with the Soviet Union developed especially as a result of close cooperation in the economic and technical issues because Soviet Union was the main ally of Turkey starting from the War of Independence up until the end of WWII. Moreover, Turkey was invited to the LoN in 1932 with the support of the Soviet Union. In 1934, Balkan Pact was signed between Turkey, Greece, Romania and Yugoslavia against the revisionist intentions of Bulgaria and potential Italian threat towards the Balkans. Furthermore, Turkey signed Saadabad Pact with Iran, Iraq and Afghanistan in 1937 to develop relations and cooperation among the parties. (Oran, 2006: 271384)

Lastly, Turkey joined Nyon Conference, which was convened for Italian attacks to the Soviet ships carrying military equipment to the republicanists who were also supported by the UK and France fighting against nationalists backed by Germany and Italy in the Spanish civil war, in 1937. (Güçlü, 2002: 53-54) Shortly, Turkey was supporting the protection of status quo in the international level and it was against revisionist policies of Italy (Mare Nostrum) and Bulgaria while there were two exceptions of this foreign policy: Montreux Convention (1936) and integration of Alexandretta (Hatay) to Turkey. (1939) Although these two developments can be regarded as deviation from status quo, they were compatible with the national interests of Turkey because Montreux Convention lifted all barriers against Turkey's jurisdiction on the straits violating its sovereignty and Alexandretta was a part of the National Oath (Misak-ı Milli) which drew the borders of Turkish foreign policy.

Atatürk's successor İnönü carried out the same foreign policy after 1938: pro-Western and pro-status quo. İnönü carried out a cautious foreign policy and balance of power strategy during his presidency and particularly during WWII. Turkey signed an agreement with the UK and France for cooperation in case of war, but it stayed out of the war despite its obligations in this agreement by claiming that France was out of the war as early as the summer of 1940. During WWII, Turkey conducted relations with the Axis and Allies particularly in the economic realm at the same time, sold chromium to both sides, and despite the 
pressure of the Allies between 1942-1945, İnönü's Turkey succeeded to stay out of the war. At the end, Turkey declared war against Germany and Japan in order to be a founding member of the United Nations. Turkey's WWII strategies and policies are still debated, but it can be argued that Turkey tried to maximize its interests by staying out of the war to protect its sovereignty and independence which its national interests necessitated to do so. ${ }^{3}$

After WWII, Turkey adapted to the changing global conjuncture and especially after the territorial claims of the Soviet Union, leader of the communist bloc, from Turkey, it joined the capitalist bloc and became a NATO member under the leadership of the United States (US) in 1952. With the emergence of the Cold War, for the decision makers, Turkey had to make a choice between two sides for its national interests and there was no room for neutrality or balance of power strategy that had been conducted in earlier decades. Rules and dynamics of international relations were changing and Turkey had to adopt these changes. Therefore, as a support against its aggressive neighbor, Soviet Union, Turkey joined the Western alliance and despite some fluctuations, particularly in the 1960s and 1970s, Turkey remained an ally of the US. In the early years of the Cold War, protection of sovereignty and independence as well as maximization of economic and military objectives were aimed to maximize in an alliance with the US. (Sander, 2016: 26-27) Furthermore, status quo meant fighting against communism and preventing Soviet expansion in the early years of the Cold War.

Consequently, during the RPP rule between 1923 and 1950, Turkey's foreign policy objectives were preservation of sovereignty and independence as well as regional and international status quo and decision makers, mainly Atatürk and İnönü, pushed hard for it. However, RPP lost the elections to DP in 1950 and new rulers would conduct similar policies in some areas although they diverged from RPP in some policies.

\section{Definition of "National Interests" and Turkish Foreign Policy (1950-1960)}

When DP came to power in 1950, it embraced RPP's US-centric foreign policy and harmonized Turkey's political, economic and military interests. In other words, DP's definition of national interests had convergences as well as divergences with the RPP: alignment with the West, particularly the US, to resist Soviet threats and pressure in order to protect sovereignty and territorial integrity or status quo. However, although the Soviet Union gave up its territorial claims

3 For more details about Turkish foreign policy during WWII see Deringil, Denge Oyunu: İkinci Dünya Savaşı'nda Türkiye'nin Dış Politikası. 
after the death of Stalin in 1953, DP government did not question the pros and cons of the US alliance because DP was more ambitious for economic development and military modernization of Turkey due to its promises to its supporters before coming to power, so it needed economic and military support of the US as well as political support. ${ }^{4}$ (Gerger, 2012: 71-74; Eroğul, 2003: 116117) In other words, DP government's foreign policy in this decade was closely interwoven with its domestic objectives and promises.

After the election victory in 1950, DP government had one main objective in foreign policy to maximize Turkey's national interests: being a member of NATO and establishing close relations with the US as soon as possible. After Turkey's membership to NATO in 1952, the main area that Turkey could prove its loyalty to the US to maximize its economic and military interests was the Middle East and DP government pushed hard for acting in accordance with the US in the region, so DP governments were actively involved in Middle East politics. (Kasapsaraçoğlu, 2015: 333) In addition, they had to cope with Cyprus crisis in the late 1950s. It can be argued that Turkey's relations with the US shaped its Middle East and Cyprus policies in this decade.

\subsection{Turkish-American Relations}

Within the context of Turkish-US relations in the 1950s, the first decision to be made by the DP was sending troops to the Korean War 1950. Turkish troops were sent to Korea and fought between 1950 and 1953 against North Korean forces. Sending troops to the Korean War was an opportunity for the DP government to develop Turkey's relations with the US and become a member of NATO. (Sander, 2016: 110-111) For RPP governments in the late 1940s and DP government, NATO membership was considered as a cure for the ills of Turkish foreign policy: resisting against Soviet threats under the umbrella of NATO and protecting sovereignty and territorial integrity of Turkey.

DP government's decision of sending troops to the Korean War was supported by the RPP despite some criticisms. The decision was in harmony with Turkey's national interests of alignment with the West and protection of status quo. However, according to RPP and its leader İnönü, a parliamentary session was necessary because sending troops to Korea was a declaration of war. However, the government sent troops to Korea without consultation and approval of the parliament. (Aydemir, 2010: 295-296) DP government replied his criticisms and argued that this was not a declaration of war, but implementation

4 For more details about social and economic pillars of DP's foreign policy and reasons of its need to the US support especially in the first half of the decade see Boratav, 2018: 110-121; Pamuk, 2014: 225-234; Yenal, 2013: 98-104; Kazgan, 2006: 78-84. 
of the $51^{\text {st }}$ article of the UN charter on collective defense. Therefore, there was no need for parliamentary session or approval. However, it is understood that as a former and experienced soldier, diplomat and president, İnönü expected to be consulted in such decisions. He stated that for national unity in foreign policy decisions such as the defense of the country or declaration of war, the government should have informed and acted in accordance with the opposition. (Toker, 1991a: 218; TBMM, t.9.s.1.v.5: 214) Nation Party (NP) supported RPP's position and emphasized the necessity of a parliamentary session and government's efforts to create national unity. (Toker, 1991a: 81)

Consequently, DP's decision of sending troops to the Korean War was criticized by the opposition regarding its method rather than the decision because it was compatible with Turkey's efforts for establishing an alliance with the West. However, government's accountability and transparency in foreign policy issues would be criticized by the opposition throughout the 1950s and it was criticized by the opposition as a factor weakening national unity and Turkey's solid stance in foreign policy. (TBMM, t.10.s.3.v.17: 807)

For DP rulers, they were representing the nation and the national interest, so there was no need for consultation to the opposition because their approaches to Turkey's interests and foreign policy were similar. DP government's decision of sending troops to the Korean War paved the way for Turkey's membership to NATO because with this decision Turkey proved its loyalty to the Western alliance, particularly the US. In order to protect Turkey's national interests, its sovereignty and territorial integrity against Soviet threats after WWII, RPP government had already applied for NATO membership in 1949, but rejected. When DP came to power, its major foreign policy objective was forming an alliance with the West and becoming a NATO member because it was regarded as the guarantee of protecting Turkey's sovereignty and territorial integrity as well as developing the economy and modernizing the army. In this vein, DP carried out similar policies to those of RPP for protecting Turkey's national interests. Turkey's participation into the Korean War accelerated Turkey's membership to the Western alliance and after the US persuaded the UK, which was planning to establish an alliance in the Middle East under its leadership, for Turkey's participation into NATO, Turkey became a NATO member in 1952. (Sander, 2016: 112-118) Taken as a guarantee of Turkey's national interests, NATO membership was supported by the opposition and it was ratified in the parliament with their support. However, they also put some reservations to Turkey's NATO alliance.

For the RPP, NATO membership was a result of Turkey's long-term efforts and sacrifice. More importantly, this membership showed Turkey's importance in the eyes of Western alliance. Turkey was entering NATO as a peaceful actor and Turkey's national policy, protection of status quo was a part 
of it, and character would prevent Turkey from conducting expansionist policies towards its neighbors. Turkey's main objective was the protection of international peace as part of the UN and after NATO membership, Turkey would not be alone in the international arena. Lastly, for the RPP, NATO membership was a national issue. (TBMM, t.9.s.2.v.13: 317-318) According to the major opposition party in the parliament, Turkey's NATO membership was in harmony with Turkey's national interests because Turkey would be a part of Western alliance and, as a result, protect its sovereignty and territorial integrity as well as status quo in the international arena. As for the RPP, an NP member stated that NATO membership was a national success as well because Turkey's traditional and peaceful foreign policy was a common policy shared by all parties. In all foreign policy issues harmonious with Turkey's interests, they would support governments in the following period. Polarization among the parties in foreign policy issues might destroy Turkey's interests, so foreign policy had to be national. (TBMM, t.9.s.2.v.13: 324; Toker, 1991a: 173)

Opposition's statements supporting NATO membership and DP government were followed by some reservations and warning from RPP leader İnönü. He separated Turkey's relations with NATO and relations with the US. He argued that as a part of NATO, Turkey would definitely fulfill its obligations, whereas conducting adventurous foreign policy or acting solely with the US rather than NATO was meaningless and incompatible with Turkey's interests. For İnönü, the US had international missions, but Turkey did not, so Turkey should support these actions like other NATO members and not go beyond its power and limits. (Toker, 1991c: 155) In addition, RPP was supporting friendly relations with the US and this friendship should be established on strong pillars, but Turkey should not lose initiative in these relations. (Toker, 1991c: 156)

In other words, for the opposition, Turkey's relations with the US and obligations in NATO should be based on mutuality and bilateralism and Turkey's national interests should be protected. This cautious and pro-status quo policy had become major principles of the RPP governments about Turkey's national interests until 1950. DP would act accordingly with Turkey's interests set by the RPP to the extent possible, but it would be criticized as being adventurous especially in the Middle East in the second half of the 1950s. (Aydemir, 2010: 333-334)

\subsection{Middle East Policy (1950-1955)}

After Turkey's membership to NATO, the Middle East turned into the most significant area to show Turkey's loyalty to the Western alliance and to reach its aims with the US support. In return, for the US, Turkey would be a significant player in Middle East defense projects and, thus, Turkey would be the 
center-of-attraction and the bridge between the region and the West. In addition, the West needed a politically, economically, and militarily strong Turkey in order to prevent Soviet expansion in the Middle East and protect Middle East oil. (FRUS 1951, v.5.i.8: 51-52) Consequently, DP government aimed to pursue an active foreign policy in the Middle East with the support of the US to maximize Turkey's national interests. On the contrary, RPP governments before 1950 avoided from involving in Middle East politics to protect Turkey's territorial integrity and the status quo, so DP's movement can be regarded as a deviation from RPP's definition of national interests regarding Middle East. However, DP reformulated Turkey's interests in the region and involved in regional politics more actively. RPP's reaction of DP's involvement in the Middle East was the following: as long as these projects were successful and in harmony with the US, the opposition supported the government. When DP government faced challenges and took risks in the crises particularly in the second half of the 1950s, they opposed and criticized government's policies.

Middle East Command (MEC) was the first project formulated by the Western powers as early as 1951 to prevent the Soviet Union from infiltrating into the region. The US and the UK intended to set up a military structure with the participation of Turkey and Egypt as the major states in the area. In addition, this structure would provide a basis for the solution of problems between Egypt and the UK particularly the UK troops and bases in Egypt. US would not participate into the command, but support it economically and militarily. (Oran, 2006: 620-621; Sander, 2016: 112-113; Bilgin, 2004: 95-98; Kürkçüoğlu, 1972: 33-48) This project was prepared by Western powers and proposed to Turkey and Egypt. Turkey supported the project although its major foreign policy goal was NATO membership at that time, but the project failed as a result of Egypt's refusal.

DP government's support to the project was praised by the RPP leader İnönü and he stated that Turkey and its neighbors had to unite against their common enemy and threat. In the region, there was a need to form such a common defense structure. He added that Turkey did not have any expansionist intentions against its neighbors and the latter should have trusted former's good will. Like Turkey, other states in the region had to support Turkey's common project with its Allies. (TBMM, t.9.s.3.v.20: 321-322) İnönü thought that preservation of Turkey's territorial integrity and regional status quo could be accomplished by the establishment of a common defense structure. However, it can be argued that he failed to understand regional dynamics and developments. The threat for Turkey and Western powers was the Soviet infiltration into the region, but, for Egypt, for example, the threat or enemy was the UK and Iraq. Shortly, there was inconsistency between perceptions and interests of the states in the region. 
Main criticism to DP's support to MEC came from Republican Nation Party (RNP). An RNP member criticized DP's support to Western powers for the establishment of a common defense because the developments in the region showed that the UK lost its popularity in the region and caused the reaction of the Middle East states. Under these circumstances, Turkey should not have conducted a pro-UK policy. However, he added that dynamics and circumstances had already changed and US and Turkey were acting together against the Soviet penetration into the region. His party was supporting DP's policy as a mediator in the solution of regional problems as well as its Israel policy. Nevertheless, he pointed out that as a newly established state, Israel was very dynamic stemming from its religious dogma, Zionism. As a result, Israel's policies had significant impact in the region and caused reaction of Arab states. According to him, Turkey should play its role for the stability of the region and, for them, decision makers in Turkey were acting in accordance with their responsibility for the region. (TBMM, t.9.s.8.v.20: 834-835)

It can be argued that for the opposition, Turkey's interests in the MEC project were development of relations with the Western alliance, particularly US, and protection of status quo in the region which were similar to DP's objectives. In other words, as long as DP's Middle East policy was compatible with these interests, opposition parties would support the government and national interests would unite political actors in the parliament. It can be argued that both the government and opposition misinterpreted the developments in the region because the split between Middle East states was a reality and threat perceptions of these states were different from each other as well as perceptions of Western powers and Turkey.

After the alliance formation project between Turkey and Egypt had failed, the US changed its strategy and during his tour in the Middle East in 1953, US Secretary of State John Foster Dulles introduced Northern Tier concept. This project would aim to form an alliance between Turkey and Iraq rather than Turkey and Egypt to prevent the Soviet Union from infiltrating into the region. Northern Tier concept was embraced by the parties involved in this alliance because it would be a tool to negotiate and maximize their interests. Particularly for Turkey, this project would protect its territorial integrity and sovereignty against a possible Soviet expansion as it would provide economic and military support from the US. During and after the formation of Baghdad Pact in 1955, member states would use this pact as a leverage to reach their economic and military objectives. (FO 371.130181. RK 10316-6)

In this process, the Turkish-Pakistani Pact was the first step in the formation of Middle East alliance. Turkish-Pakistani Pact, officially the Treaty of Friendship between Turkey and Pakistan, was signed on April 2, 1954. In this treaty, Turkey and Pakistan agreed on consulting each other about international 
issues of their common interests and cooperating in cultural, economic and technical issues. The sixth article of the treaty stated that the agreement would be open to other states in the region. In other words, the Pact might be turned into a common defense structure with the participation of other Middle East states. (Oran, 2006: 622; Kürkçüoğlu, 1972: 54) Opposition in the parliament supported this pact because Turkey's territorial integrity and the status quo in the region would be preserved by such an alliance aiming at preventing the Soviet Union from expanding southwards. (TBMM, t.10.s.F.v.1: 150-156) The TurkishPakistani pact did not turn into an alliance system as intended, but it paved the way for the establishment of the Baghdad Pact alliance.

After long negotiations between Turkey and Iraq, the Baghdad Pact was signed on February 24, 1955 as a result of the initiative to form an alliance in the Middle East against the Soviet infiltration. Turkey pushed hard for it because it would play its role as a bridge between the region and the West, and, as a result, it would be supported by the US politically, economically and militarily. After Turkey and Iraq, Iran, Pakistan and the UK joined the Pact. With the establishment of Baghdad Pact alliance, it was assumed that the pact would unify all the states in the region against the Soviet expansion. However, the pact caused a split in the region because the second half of 1950s witnessed the rise of Arab nationalism under the leadership of Gamal Abdel Nasser, who dominated Egyptian politics after Free Officers Coup in 1952 and became the president in 1954, and for these countries the main threat and enemy was not the Soviet Union, but Israel.

The pact was supported, implicitly or explicitly, by states such as Jordan and Lebanon which needed US support for economic development and military modernization as pact members. However, participation of the UK and US support to the pact, despite the lack of formal membership, caused anti-pact propaganda in states such as Egypt and Syria which were supported by the Soviet Union economically and militarily. Ultimately, the pact widened the split in the region, and, thus, states such as Jordan and Lebanon hesitated to join the pact due to their fear of Egypt and fear of hostility between Egypt and Iraq as the most powerful Arab states. In addition, especially for Lebanon, the threat of Israel with which it faced hostility and conflict, prevented them from joining a pact which was explicitly criticized by Egypt. (Sander, 2016: 174-186; Kürkçüoğlu, 1972: 55-82)

Although the formation of Baghdad Pact caused problems in the region, DP government's policy was supported by the opposition because according to members of opposition parties, it would protect the status quo in the region by preventing the Soviet Union from infiltrating into the region as well as Turkey's territorial integrity. Shortly, for the opposition, Baghdad Pact was compatible with Turkey's national interests. An RPP member stated that despite conflicts 
and problems in domestic politics, RPP would support DP's foreign policy. The Baghdad Pact was an indicator of Turkey's loyalty to the world peace and willingness of protecting it and DP's foreign policy was based on Turkey's commitment to peace and democracy. (TBMM, t.10.s.1.v.5: 231) Another RPP member argued that the aim of the pact was the establishment of close cooperation between two states. However, some articles of the treaty needed some clarification due to the vagueness of the treaty about military obligations and their impact on Turkey's rights and commitments in NATO. He also said that the Baghdad Pact was a peaceful agreement and it did not include any commitments against any state in the Middle East. (TBMM, t.10.s.1.v.5: 811812) As RPP, RNP supported the Baghdad Pact and according to RNP, such policies were compatible with Turkey's interests. Therefore, the Baghdad Pact with the ally was serving for regional peace and defense, so there was an agreement between RNP and DP in such national issues. (TBMM, t.10.s.1.v.5: 811-812)

For the DP government and the opposition, Baghdad Pact would serve Turkey's national interests such as the preservation of status quo in the region by preventing the Soviet Union from expanding and establishing peaceful relations among the states in the region to protect Turkey's territorial integrity and sovereignty. In addition, for the government, as all pact members, it would assure economic and military support to Turkey from the US. However, both the government and the opposition misinterpreted the developments in the region and analyzed the Baghdad Pact only from Turkey's perspective. As time passed, the Baghdad Pact caused conflicts and hostility in the region, even between the Arab states like Iraq and Egypt competing for the leadership of the Arab world, rather than establishing peaceful relations.

Therefore, Turkey was involved in these conflicts and the government conducted so-called adventurous policies towards the region, so, the support of opposition parties began to decline as DP's Middle East policy began to be considered as harmful to the regional status quo and Turkey's sovereignty and territorial integrity. Opposition parties began to criticize DP's Middle East policy in the second half of the 1950s. For example, an RPP member argued that the pact did not reach its goal and it was involved in the insoluble problems of the region, but Arab states did not join the pact as opposed to the expectations of Menderes governments. DP government was responsible for such a result due to its conflicting policies. He also criticized prime minister Menderes' statement that 'Baghdad Pact included all possibilities for the solution of all problems in the Middle East including the Palestine problem.' For the RPP member, these issues were far beyond the aims of the pact. (TBMM, t.11.s.1.v.2: 620) In another speech, he stated that Baghdad Pact did not reach its goal because the pact was formulated as a setback to a threat from the North, while it got stuck into the 
problems of the South. With such policies, Turkey lost its prestige in the region. (TBMM, t.11.s.1.v.2: 628)

Shortly, as DP government's Middle East policy served Turkey's national interests such as the protection of status quo in the region and preservation of Turkey's territorial integrity, the opposition, particularly RPP, supported the government. When DP government involved in conflicts and crises in the region, opposition parties raised their objection and criticism.

\subsection{Middle East Policy (1955-1960)}

The second half of the 1950s witnessed several conflicts and crises in the Middle East such as the nationalization of Suez Canal by Egyptian leader Nasser and Israeli attack to Egypt with the support of the UK and France in 1956, Turkish-Syrian border crisis in 1957 and successive crises in Iraq, Lebanon and Jordan in 1958. The Baghdad Pact caused a split in the region and the Eisenhower Doctrine in 1957, which aimed to give economic and military support to the states having friendly relations with the US deteriorated the situation. In accordance with Turkey's national interests followed by the DP and shared, to some extent, by the opposition, DP government conducted an active policy and involved in these crises. DP government was trying to maximize Turkey's political, economic and military interests by showing its loyalty to the US. However, for the opposition, involvement in regional crises endangered the status quo in the region and Turkey's territorial integrity. In other words, the consensus between the government and the opposition began to disappear in the second half of the decade.

The first crisis that the DP government had to deal with was the Suez Canal crisis and the Israeli attack to Egypt in 1956. After the nationalization of the Suez Canal by Egyptian president Gamal Abdel Nasser upon the US and UK rejection of financing the construction of Aswan Dam and the development of close relations between Egypt and the Soviet Union in return, first London Conference was convened on August 26, 1956. In this conference, participant states discussed proposal of US Secretary of State Dulles and agreed that Suez Canal would be administered by an international commission established by the UN and passage of ships from the Canal would be free. After London Conference, Cairo meetings were convened between the Committee established in London Conference and Egypt, but Nasser rejected these proposals and second London Conference was convened.

Turkey participated in these conferences, became a member of Five Nations' Proposals following the US and insisted on the peaceful solution of the crisis and freedom of passage through the canal. (FRUS 1955-57, v.16.i.8: 250252) However, for the DP government, as for the US, Egypt and its leader Nasser 
were mainly responsible for the crisis because of its rapprochement with the Soviet Union that caused Soviet infiltration to the region after US and UK had rejected financial support to Aswan Dam project. (Kürkçüoğlu, 1972: 82-104; Sander, 2016: 200-205; Oran, 2006: 627-629; Kamrava, 2005: 94-96; Cleveland, 2008: 343-348) Therefore, DP government, as seen in acting minister of foreign affairs Ethem Menderes' speech in the parliament, continued criticizing Egyptian leader Nasser and the Soviet Union for this crisis in the following period. (TBMM, t.10.s.3.v.17: 802-803)

Upon the failure of the Committee and the UN Security Council, Israel attacked Egypt with the support of the UK and France to enforce it to accept decisions made during London Conferences. In the meantime, the US and Soviet Union intervened and Israeli troops were withdrawn from Egyptian territories. During the Israeli attack to Egypt, Turkey continued its pro-American policy and declared a communique with Baghdad Pact members, except UK, to denounce Israeli attack and put pressure on the UK to accept US proposals. Furthermore, it withdrew its ambassador from Tel Aviv as a diplomatic reaction while it did not react to the UK and France similarly. (FO 371. 121793. VR 1091-766,767)

DP government's policy during Suez crisis and the following Israeli attack to Egypt was criticized by the opposition. For example, Turan Güneş from Freedom Party (FP) criticized DP government's policy against Egypt and stated that Turkey should have played an intermediary role in the solution of crisis rather than taking a side against Egypt. (TBMM, t.10.s.3.v.17: 808-809) In addition to FP, RPP urged the government and its member Turgut Göle stated that Turkey's role in the solution of Arab-Israeli conflict should not go beyond cooperating with the UN, the US and the UK. (TBMM, t.10.s.3.v.17: 810) Shortly, according to opposition parties, Turkey should have acted more cautiously and strategically rather than taking a side in this process refrained from intervening in crisis. Moreover, the role of Turkey in the solution of Arab-Israeli conflict should not go beyond cooperation with the UN and its Western Allies.

After the settlement of Suez Crisis, DP government involved in a border crisis with Syria. Syria was one of the pro-Soviet states in the region and it signed a treaty of economic and technical cooperation with the Soviet Union on August 6,1957 . This treaty accelerated the Soviet infiltration, at least in the eyes of Western powers and Turkey, into the region and caused resentment and reaction against Syria and the Soviet Union. The US declared that it would not intervene and support a military intervention in Syria, but DP government began to mobilize troops in the southern border because it perceived Soviet existence and the spread of communism in Syria as a threat to Turkey's territorial integrity. (FO 371. 128242.VY 10344-4,5; FRUS 1955-57, v.13. i.13: 642-4, 650, 656-7, 7001) It can be argued that Turkey did not aim to intervene in Syria, but, in addition to its perception of threat, Turkey needed economic and military support from 
the US because Turkish economy was in crisis and after a while election would be held. Furthermore, Turkish army was not strong enough to resist to a possible attack from its northern or southern neighbor, so Turkey wanted to push the US for economic and military aid. For the US officials, the reports showing the Soviet presence in Syria were exaggerated, but Turkey should have been supported militarily against a possible attack. (Sander, 2016: 224; Sever, 1997: 203; FRUS 1955-57. v.24. i.13, 702-704, 704-6)

As a result of the mobilization of troops in the Turkish-Syrian border, the Soviet Union and Syria reacted against Turkey and Soviet prime minister Nikolai Bulganin sent a letter to prime minister Menderes in which he accused Turkey of preparing an attack to Syria in collaboration with the United States. In return, prime minister Menderes replied these accusations and accused the Soviet Union of using the problem for its own interests. (FRUS 1955-57. v.24. i.13, 734) In the meantime, Saudi King tried to intervene for mediation between two states while Syria rejected the proposal although Turkish minister Zorlu visited Riyadh to discuss these mediation efforts with the Saudi King, but could not agree. (FO 371. 128243. VY 10344-70) The Soviet Union and Syria pushed for UN intervention into the crisis and UN held a meeting to discuss the crisis between Turkey and Syria. However, UN General Council rejected to discuss the issue and agreed that Turkey and Syria would solve their problem through bilateral meetings. In time, the tension between two states decreased and it did not turn into a more serious crisis. (Kürkçüoğlu, 1972: 104-128; Sander, 2016: 212-225; Oran, 2006: 629-632)

However, opposition parties criticized DP's policy during the border crisis. RPP member Necati Ilter stated that the prime minister was talking about a threat from Syria and in the atmosphere of the general elections, such a threat might have been useful. However, they did not know the source of the threat. (TBMM, t.11.s.1.v.2: 630-631) In other words, for the opposition, Syrian threat was not persuasive. After these criticisms, minister Zorlu made a speech and argued that there was a communist threat in Syria and Turkey had to take action to prevent this threat, so DP's policy during the border crisis with Syria was legitimate and they did not abuse the threat in Syria for the elections. (TBMM, t.11.s.1.v.2: 643644)

In the same session, Illter evaluated DP's Middle East policy in general and heavily criticized it. According to him, as an experienced state in Middle East politics, Turkey should not have conducted such a policy. For him, Middle East was a battle ground for big powers and there was no room for smaller states to conduct effective policies independently. He also criticized Turkey's Israel policy and stated that Turkey took a risk by sacrificing its relations with Israel for the Baghdad Pact. However, the reflection of Turkey's Middle East policy was seen in Arab states' negative stance towards Turkey's Cyprus policy. Therefore, DP's 
Middle East policy was a failure because of DP government's involvement in regional crises. These problems should have been solved by the UN, not the Baghdad Pact. For him, Nasser had been accepted as the leader of the Arab world regardless of Turkey's opinion and Menderes governments were not realistic because they considered that Iraq's participation into the Baghdad Pact had brought regional stability and other Arab states would have ultimately joined the pact. However, the government failed because all these assumptions proved to be wrong. Despite the impossibility of these assumptions, Menderes governments had tried very hard to persuade Arab states to join the pact. (TBMM, t.11.s.1.v.2: 620-621, 629) Shortly, these statements reflect RPP's approach to Turkey's Middle East policy. As long as DP's policies were cautious and pro-status quo serving for Turkey's national interests, RPP and other opposition parties supported the government. When the government did not act in harmony with these objectives, however, they did not support, but heavily criticized the government.

After the appeasement of crises between Turkey and Syria, Egypt and Syria jointly declared that they established the United Arab Republic (UAR) on February 1, 1958. As a response to this union, Iraq and Jordan established Federal Arab State on February 14, 1958. Turkey recognized these unions as great powers did because, for Turkey, especially Syrian integration with Nasser's Egypt was preferable to Soviet domination and influence in Syria because the main concern of DP government regarding Syria was the infiltration of the Soviet Union and expansion of communism. (FO 371. 131338. JE 10344-1; Cleveland, 2008: 348350; Oran, 2006: 631) In harmony with Turkey's expectations, Syrian Communist Party was banned and communism was outlawed in Syria after the establishment of the UAR. RPP member Necati İlter made a statement on the establishment of UAR and urged the government stated that 'the establishment of the United Arab Republic between Egypt and Syria was a significant response to the Baghdad Pact and caused excitement in the region. In addition, Turkey's recognition of the federation between its ally Iraq and Jordan was also natural. These developments necessitated that the Baghdad Pact should not go beyond its mission and the solution of the problems in the region and the protection of the region should be left to the UN. (TBMM, t.11.s.1.v.2: 632-633)

In other words, RPP urged the government once again to conduct cautious and realistic policies not to deepen the division and rivalry in the region. Nevertheless, the Middle East would be shaken by several successive crises in 1958. On July 14, 1958; the military junta led by General Abdel Qarim Qassim toppled down the Iraqi government and King Faisal, Crown Prince Abdulillah and prime minister Nuri Said were killed. After the coup, some rumors about a possible Turkish intervention in Iraq began to circulate especially in the West. For example, US officials like secretary of state John F. Dulles and CIA director 
Allan Dulles thought that Turkey might intervene in Iraq with the approval and support of the US. (FRUS 1958-1960, v.12.i.9: 307-311) However, DP government did not involve in such a crisis and Turkey recognized the new government in Iraq following Western powers on July 31, 1958 in harmony with its pro-American foreign policy. (Kürkçüoğlu, 1972: 128-143; Sander, 2016: 225-232; Oran, 2006: 632; Cleveland, 2008: 363-374) In the following period, major issues between Turkey and Iraq would be the status of Turkish community and the possibility of the establishment of a Kurdish state in Northern Iraq, but these issues did not turn into serious crises between two states. (FO 371. 134212. VQ 10344-3)

From the opposition, RPP leader İnönü heavily criticized these rumors especially published in American journals and DP's policy during the coup d'état in Iraq. (TBMM, t.11.s.1.v.4: 843-844) After İnönü had made his speech, minister Zorlu replied his accusations and rejected all the rumors about Turkey's intervention in Iraq. (TBMM, t.11.s.1.v.4: 848) These criticisms were reflecting İnönü and RPP's foreign policy vision: non-intervention in crises in the Middle East and protection of status quo in the region to protect Turkey's sovereignty and territorial integrity. In other words, approaches of the government and the opposition to Turkey's interests were somewhat conflictual regarding the Middle East: the government followed Western powers, specifically the US, in the recognition of new regime in Iraq, but at the beginning DP government was against the coup d'état. For the RPP, the government should act calmly and cautiously rather than being involved in this crisis. RPP's stance towards the preservation of status quo in the region and non-involvement in crises was seen in its leader's statements during budget discussions in February 1960. (TBMM, t.11.s.3.v.12: 498) İnönü stated that Turkey had nothing to gain from being involved in conflicts and crises in the region. (Toker, 1991b: 220) Therefore, Turkey should formulate its foreign policy to protect or maximize its own interests. (TBMM, t.11.s.1.v.4: 844; t.11.s.3.v.12: 498)

Consequently, DP governments acted pragmatically, but not strategically due to their misinterpretation of dynamics of the Middle East such as rising Arab nationalism, anti-Zionism and rivalries among Arab states, and conducted proAmerican policies in the region against the Soviet Union to reach their political, economic and military objectives: preservation of Turkey's territorial integrity, sovereignty or status quo in the region as well as economic and military interests. DP governments supported MEC project in 1951 and signed the Baghdad Pact in 1955 as a result of its harmonious relations with the US. On the other hand, the opposition, especially RPP, supported the government because these developments were regarded compatible with Turkey's national interests. However, in the second half of the decade, DP government took some risks and involved in regional crises. These policies were heavily criticized by the 
opposition because they were considered as conflictual with Turkey's national interests particularly the preservation of status quo in the region and ultimately Turkey's sovereignty and territorial integrity.

\subsection{Cyprus Policy}

As Turkey's Middle East policy, which was full of problems in the second half of the 1950s, Cyprus turned into a trouble in Turkish foreign policy in the same period. When the UK was about to end its rule in the island in the late 1940s, Greek community's political activities accelerated and, ultimately, they began to claim their independence and unity with Greece as a part of their ENOSIS (unification) policy. However, for the RPP governments in late 1940s and DP governments in the 1950s, there was no Cyprus Question. (Oran, 2006: 596-598)

Nevertheless, Cyprus Question began to turn into a non-negligible and chronic issue starting from mid-1950s. Greeks and Turks in the island began to mobilize and some underground organizations like EOKA (Etniki Organosi Kipriaku Aragos-National Organization of Cyprus Struggle) and Turkish Resistance Organization (Türk Mukavemet Teşkilatı) were established. Upon the deterioration of relations between two communities in the island, the UK invited Turkey and Greece on June 20, 1955 to a meeting in London for the solution of problems in the island. In the conference, all parties made their proposals. In the meantime, the UK changed its policy and began to insist controlling the whole island in order to fulfill its obligations in NATO and the Baghdad Pact. The Greek side argued that self-determination rights of Greek Cypriots had to be recognized. In return for these claims, Turkish minister Zorlu emphasized the need to protect the status quo in the island due to geographical, historical, social and strategic reasons for Turkey. He added that if the status quo in the island was to change, the island should be given back to Turkey. (TBMM, t.10.s.2.v.10: 739; Oran, 2006: 600-602) After negotiations between the UK, Turkey, Greece and representatives of Cypriot and Turkish communities in the island, Zurich and London Agreements were signed in 1959, and Cyprus Republic was established as a bi-zonal and bi-communal entity in 1960. (Oran, 2006: 603-610)

At the beginning, DP government's approach to Cyprus Question was the preservation of status quo which means the continuation of the UK rule in the island. However, as the government could not agree on the protection of status $q u o$, they pushed hard for dividing the island or at least gaining the rights to guarantee. Zurich and London Agreements did not divide the island, while it granted rights to guarantee to Turkey. However, for the opposition, national interests of Turkey necessitated the division of the island between Turks and Greeks, so Zurich and London Agreements were criticized by the opposition. 
Opposition parties voted against these agreements because they had some reservations and suspicion about the future of the newly established state. RNP member Ahmet Bilgin stated that the future of Cyprus should have been decided by the UK and Turkey because Greece had not ruled the island in the past. He added that government's policy caused resentment and reaction in the society. (TBMM, t.10.s.2.v.10: 719-720)

Opposition parties continued to criticize government's policy in the following period. RPP member Necati İlter argued that government's policy was not farsighted, stubborn and influential and Arab states voted against Turkey's rights in the island in the UN and this policy caused conflicts with the UK. (TBMM, t.11.s.1.v.2: 620) After these criticisms, minister Zorlu made a speech and argued that Greece, as well as Turkey and the UK, had been a party in Cyprus Question from the beginning. Furthermore, there was no conflict between Turkey and the UK. (TBMM, t.11.s.1.v.4: 641-642) RPP member Bülent Ecevit stated that he was suspicious about the success of the solution in the island and he stressed that Turkish Cypriots should be supported economically. (TBMM, t.11.s.3.v.12: 502-503, 505)

After Ecevit's speech on Cyprus, minister Zorlu stated that London and Zurich Agreements would protect the rights of communities in the island as well as Turkey's security. Two agreements would serve for the development of friendly relations between Turkey and Greece as well as relations between Turkish and Greek communities in the island. In addition, economic situation of Turkish community in the island was better than the past and would be better in the future.

Consequently, Cyprus Question ended up with the change of status quo in the island although London and Zurich Agreements granted guarantee rights for Turkey. DP government emphasized Turkey's rights in the agreements and defended its Cyprus policy while opposition parties criticized government's Cyprus policy and the agreements. For the opposition, the island should have been divided between Turkish and Greek communities due to the possibility of inter-communal conflicts. Shortly, the status quo in the island should have been protected unless it had not been divided. As DP government's Middle East policy in the second half of the 1950s, Cyprus policy was regarded by the opposition as deviation from Turkey's national interests especially the preservation of status quo.

\section{Conclusion}

After the establishment of the republic, national interests were defined as development of relations with the West, protection of sovereignty and territorial integrity or status quo. To this end, the new regime pushed hard for the solution 
of problems left from Lausanne Treaty and establishment of friendly relations not only with its neighbors, but also with Western powers. During WWII, for the preservation of sovereignty and territorial integrity, Turkey had to conduct a balance of power strategy and, firstly, it did not join the war, and, secondly, it conducted relations with both sides especially in the economic realm. However, with the emergence of the Cold War, global conjuncture changed and for the decision makers Turkey must have reoriented its foreign policy and adapt to the new dynamics of international relations. With keeping its core national interests, i.e. protection of sovereignty and territorial integrity or status quo intact, national interests were re-defined by RPP and, to the extent possible, sustained by the DP.

In this period, protection of status quo was defined as the struggle against the expansion of communism and the Soviet Union and the West meant the US rather than the UK and France. In the 1950s, DP government had to deal with several issues in foreign policy such as the development of Turkey's relations with the US, Turkey's engagement in the Middle East and the eruption of the Cyprus Question in the second half of the decade. In this period, opposition in the parliament, mainly RPP, regarded foreign policy as a national issue that should be supported by the whole nation. Despite their support to DP's UScentric foreign policy, which was regarded as the guarantee of protecting sovereignty and territorial integrity or status quo as well as realizing economic development and military modernization, they raised their objections and criticisms to DP government's Middle East policy, especially in the late 1950s, and Cyprus policy because these issues were endangering Turkey's national interests for the opposition.

Consequently, when DP governments implemented cautious and strategic policies in accordance with the national interests of Turkish foreign policy such as Westernization, protection of status quo and sovereignty, the opposition supported DP governments. On the contrary, when they acted outside these borders and implemented so called adventurous policies such as the developments in the Middle East or Cyprus Question in the second half of the 1950s, the opposition heavily criticized the government. Therefore, there were divergence and convergence in the definition of national interests between the government and the opposition in the 1950s.

\section{References}

Akalın, Cüneyt. (2003), Soğuk Savaş, ABD ve Türkiye: Olaylar-Belgeler (1945-1952) (İstanbul: Kaynak Yayınları)

Aydemir, Şevket Süreyya. (2010), Íkinci Adam 1950-1964 (İstanbul: Remzi Kitabevi) 
Bilgin, Pınar. (2004), Regional Security in the Middle East: A Critical Perspective (London: Routledge) Boratav, Korkut. (2018), Türkiye Iktisat Tarihi 1908-2015 (Ankara: İmge Yayınevi) Burchill, Scott (ed). (2005), Theories of International Relations (New York: Palgrave Macmillan) Cleveland, William. (2008), Modern Ortadoğu Tarihi (İstanbul: Agora Kitaplığı)

Demirci, Sevtap. (2011), Belgelerle Lozan: Taktik-Stratejik-Diplomatik Mücadele 1922-1923. (İstanbul: Alfa Yayınları)

Deringil, Selim. (2007), Denge Oyunu: Ikinci Dünya Savaşı'nda Türkiye'nin Dış Politikası (İstanbul: Tarih Vakfı Yurt Yayınları)

Eroğul, Cem. (2003), Demokrat Parti: Tarihi ve Ideolojisi. (Ankara: İmge Kitabevi)

Foreign Relations of the United States (FRUS) 1951.v.5.i.8/ 1955-57. v.13.i.13/ v.16.i.8/ v.24.i.13/ 1958-60. v.12. i.9.

Furniss, Edgar S. and Richard C. Snyder. (1955), An Introduction To American Foreign Policy.(New York: Rinehart)

Gönlübol, Mehmet (ed). (1996), Olaylarla Türk Dış Politikası (Ankara: Siyasal Kitabevi)

Güçlü, Yücel (2002), “The Nyon Arrangement of 1937 and Turkey”, Middle Eastern Studies, 38 (1): 53-70

Gerger, Haluk. (2012), Türk Dış Politikasının Ekonomi Politiği (İstanbul: Yordam Kitap)

Günver, Semih. (1985), Fatin Rüştü Zorlu'nun Öyküsü (Ankara: Bilgi Yayınevi)

Kamrava, Mehran. (2005), The Modern Middle East (California: University of California Press)

Kasapsaraçoğlu, Murat. (2015), "Harmonization of Turkey's Political, Economic and Military Interests in the 1950s: Reflections of Turkey's Middle East Policy”, Turkish Studies, 16 (3): 332-348.

Katzenstein, Peter. (1996), The Culture of National Security (New York: Columbia University Press)

Kazgan, Gülten. (2006), Tanzimat'tan 21. Yüzyıla Türkiye Ekonomisi (İstanbul: Bilgi Üniversitesi Yayınları)

Kuneralp, Zeki. (1999), Sadece Diplomat. (İstanbul: ISIS Press)

Kürkçüoğlu, Ömer. (1972), Türkiye'nin Arap Ortadoğu'suna Karşı Politikası 1945-1970 (Ankara: SBF Yayınları)

Morgenthau, Hans. (1948), Politics Among Nations: The Struggle for Power and Peace (New York: Knopf)

Mütercimler, Erol and Mim Kemal Öke. (2004), Düşler ve Entrikalar: Demokrat Parti Dönemi Türk Dış Politikası. (İstanbul: Alfa Yayınları)

Oran, Baskın (ed). (2006), Türk Dış Politikası. (İstanbul: Iletişim Yayınları)

Pamuk, Şevket. (2014), Türkiye'nin 200 Yıllık Iktisadi Tarihi (İstanbul: Türkiye İş Bankası Kültür Yayınları)

Public Record Office (PRO), FO 371.121793/128242/128243/130181/131338/134212.

Republic of Turkey. TBMM Tutanak Dergisi. t9. s1. v.5/t9. s2. v.13/t9. s3. v.20/t10. sF. v.1/t10. s1. v.5/t10. s2. v.10/t10. s3. v.17/t11. s1. v.2/t11. s1. v.4/t11. s3. v.12

Rosenau, James N. (2006), The Study of World Politics: Theoretical and Methodological Challenges (London: Routledge)

Sander, Oral. (2016), Türk-Amerikan Ilişkileri 1947-1964 (Ankara: İmge Kitabevi) 
Sever, Ayşegül. (1997), Soğuk Savaş Kuşatmasında Türkiye, Batı ve Ortadoğu 1945-1958 (İstanbul: Boyut Kitapları)

Toker, Metin. (1991), Demokrasimizin İsmet Paşalı Yılları: DP'nin Altın Yılları 1950-1954 (Ankara: Bilgi Yayınevi)

Toker, Metin. (1991), Demokrasimizin Ismet Paşalı Yılları: DP Yokuş Aşağı 1954-1957 (Ankara: Bilgi Yayınevi)

Toker, Metin. (1991), Demokrasimizin Ismet Paşalı Yılları: Demokrasiden Darbeye 1957-1960 (Ankara: Bilgi Yayınevi)

Tuncer, Hüner. (2013), Menderes'in Dış Politikası: Batı’nın Güdümündeki Türkiye (İstanbul: Kaynak Yayınları)

Weldes, Jutta. (1999), Constructing National Interests: The United States and Cuban Missile Crisis (Mineapolis: University of Minnesota Press)

Yenal, Oktay. (2013), Cumhuriyet'in Iktisat Tarihi (İstanbul: Türkiye İş Bankası Kültür Yayınları)

Yeşilbursa, Behçet Kemal. (2005), The Baghdad Pact: Anglo-American Defense Policies in the Middle East (London: Frank Cass)

Yetkin, Çetin. (2011), Türkiye'de Askeri Darbeler ve Amerika (Ankara: Kilit Yayınları) 